\title{
6 歳児の道徳判断における情報探索と因果推論
}

\author{
竹 村 和 久* 渡 辺 弥 生** \\ INFORMATION SEEKING AND CAUSAL INFERENCE IN MORAL \\ JUDGEMENT OF SIX-YEAR-OLD CHILDREN
}

\author{
Kazuhisa TAKemura And Yayoi Watanabe
}

\begin{abstract}
The purpose of this study was to investigate information seeking and causal inference in moral judgement of 6-year-old children. The subjects were 59 kindergarten pupils. The original moral judgement task used a pair of stories contrasting intent and consequence in the Piagetian manner. The experimental conditions were as follows : GI : a condition for an absence of intent information about a good intent person ; BI : a condition for an absence of intent information about a bad intent person ; GC : a condition for an absence of consequence information about a good intent person ; and $\mathrm{BC}$ : a condition for an absence of consequence informaotion about a bad intent person. In each condition, the subjects were asked which person was naughtier, and were also asked to make inferences about the missing information. The main results were as follows : (1) Only 8.5 percent of all subjects sought causal information in the stories ; (2) Only 32.2 percent of all subjects made causal inferences about missing information in the stories ; and (3) The subjects in the $\mathrm{BC}$ condition sought more causal information and made more causal inference than the subjects in any other conditions.

Key words : moral judgement, causal inference, information seeking, choice under uncertainty, infant.
\end{abstract}

Piaget (1932) は, 子供の道徳判断には, 行為の結果 に基づいて善悪を判断する客観的判断と，行為の意図 や動機に基づいて判断する主観的判断があり，前者か ら後者へと年齢とともに変化することを指摘した。そ して, 彼は, 結果への注目または意図への注目が一貫 してなされない場合は移行期であるとした。Piaget （1932）は，意図が悪く結果の損失が小さい主人公と, 意図が善く結果の損失の大きい主人公とが登場する 2 つの例話を用いて，被験児にどちらの主人公が悪いか という道徳判断をさせた。前者が後者より悪いと判断 すると主観的判断と評定され, 後者が前者より悪いと

* 光華女子短期大学 (Koka Women's Junior College)

** 静岡大学 (Shizuoka University)
判断すると客観的判断と評定される。しかし，この実 験課題では, 結果に注目するのか意図に注目するのか の二者択一しか許されていないので, 意図と結果の両 者を考慮に入れた多次元的判断の可能性を検討するこ とができない。

このような二者択一による形式ではなく，何段階か の評定尺度によって, 道徳判断を行う方法が, 多くの 研究者によって採用されている。この試みによって, 意図か結果かという形式ではなく，各々の次元の相対 的重要度を検討することができるようになっている。 例えば, Hebble (1971) は, 意図の善悪と損失の大小を 組合わせた 4 種類の事例に対する反応を測定して, 児 童の道徳判断の発達を検討している。同様の研究は, Buchanan \& Thompson (1973), Costanzo, Coie, 
Grumet, \& Farnill (1973), Farnil (1974) によってもな されている。また, 評定尺度形式の研究ではないが, Gutkin (1972) や二宮 $(1980,1982)$ は，意図の善悪と損 失の大小とを組合わせた 4 種類の事例に対する一対比 較の反応パターンをカテゴライズして, 児童の各発達 段階における意図と結果の相対的重要度を検討してい る。これらの研究は, 発達に伴って, 結果から意図へ の重要度と移行してゆくことを示している。

さらに，意図と結果の相対的重要度だけではなく， 意図と結果の情報がいかに統合されているかの研究も 行われている。例えば, Grueneich (1982) は, 意図 3 水準と結果 3 水準とを組合わせた 9 条件における児童 の反応を，Anderson(1974) の情報統合理論を用いて検 討している。同様の研究は, Surber (1977), Leon (1980), 坂上・難波・小倉（1982）によって，行われて いる。これらの研究結果は, どの年齢集団の子供にお いても，その大半が，意図と結果の両次元を利用した 線形形式の情報統合をもとにした判断を行っているこ とを示唆している。

以上のような道徳判断における意図情報と結果情報 の相対的寄与の研究や情報統合ルールについての研究 は, 道徳判断過程について多くの知見を生み出してい る。しかし, これらの研究には, 問題点がある。それ は，これらの研究が人間の判断における自発的で能動 的な情報探索や推論過程を扱っていないことである。 現実の状況をふりかえると情報が暧昧であったり欠損 したりした不確実な状況の下で，我々は情報探索や推 論を行い，何らかの判断をしなければならないことが 多い (cf. Kahneman. Slovic, \& Tversky, 1982)。

Leon (1980) は, 結果情報または意図情報のみを小学 生と大学生に与えて道徳判断を評定法で行わせ, 意図 と結果の両方の情報を提示した場合との比較を行った。 その結果, 大学生においては, 一方の情報のみを与え られた際の判断と両方の情報を与えられた際の判断が 平行的な関係にあり，両者とも Anderson（1974）の平 均モデルによる予測と一致していた。このことは，大 学生においては, 意図あるいは結果だけの情報を与え られても他方の欠損情報を推論することにより，意図 と結果の情報統合がなされることを示唆している。一 方, 小学生では, 両方の情報を与えられた場合は Anderson (1974) の平均モデルでの当てはまりがよくなっ たが，一方のみの情報を与えられた場合には，大学生 のように，両方の情報を与えた場合の結果との間に平 行な関係はみられなかった。この結果は，小学生では, 意図あるいは結果だけの情報を与えられても他方の欠
損情報を大学生のように推論することがないことを示 唆している。

しかし, Leon (1980) の研究では, 判断結果のみから 被験児の因果推論を推測しているので，実際には被験 児の因果推論過程を検討していない。そこで本研究で は，このような情報の欠損状況を設けて，幼児の道徳 判断における因果関係についての情報探索や因果推論 について検討する。

ところで, 人間の因果推論に関する研究は, 原因か ら結果を予測する過程 (予測過程) の方が, 結果から原 因を推測する過程（帰属過程）より容易であることを示 している (Tversky \& Kahneman, 1982)。また，因果推論 に関する研究は，社会的に望ましくない結果の原因帰 属過程が社会的に望ましい結果の原因帰属過程より容 易であることを示唆している (Jones \& Davis, 1965)。発 達のどの段階でこのような因果推論の非対称性が現れ るのか, 幼児においてすでにこの非対称性は観察され るのか, というような問題も検討する必要があろう。

本研究の主目的は，以下のとおりである。すなわち， 第 1 に，幼児は欠損情報のある不確実な状況ではどの ような道徳判断をするかを検討すること，第 2 に，幼 児はそのような不確実な状況での道徳判断過程におい てどのような因果情報探索や因果推論を行うのかを検 討すること, 第 3 に, 幼児は道徳判断における因果情 報探索や因果推論において，予測過程と帰属過程の非 対称性，社会的望ましさに関する非対称性を示すのか を検討することである。本研究では，社会的望ましさ の異なる原因あるいは結果の情報を部分的に欠損させ た例話を被験児に与えることによって，幼児の道徳判 断過程における因果情報探索や因果推論を検討した。

\section{方法}

被験児 本研究の被験児は, 茨城県下の私立幼稚園 児59名(男子 29 名，女子 30 名)であった。なお，被験児は すべて 6 歳児であった。Piaget (1923) によると，因果 関係の把握の仕方は，6歳までの幼児と 7,8 歳の児 童とで大きく変異する。6 歳児までの幼児は, 因果関 係をすべて心理的動機づけの観点から把握する傾向が あるが， 7，8歳の児童では，心理的動機づけによる 因果関係の説明と論理的正当化に基づく因果関係を区 別することができるようになる。本研究では, Piaget (1923) のこの指摘を参考にして, 因果認識の発達過程 において比較的早期に相当する 6 歳紧を対象とするこ とにした。

実験の概要と実験条件 Piaget（1932）の用いたよう 
な二者択一形式の道徳判断課題の例話における主人公 の意図あるいは結果の情報を部分的に欠損させること によって, 不確実な状況下での被験児の道徳判断にお ける情報探索や因果推論過程を検討した。実験条件は, 意図の善い例話中の意図の情報のみが除かれる条件 (GI 群), 意図の悪い例話中の意図の情報のみが除かれ る条件 (BI 群), 意図の善い例話中の結果の情報のみが 除かれる条件(GC 群), 意図の悪い例話中の結果の情報 のみが除かれる条件(BC群)の 4 条件であり, 被験児を 無作為にこれらの条件のいずれかに割当てた。

提示された例話 Piaget (1932) の道徳判断課題で用 いられた例話を参考にして作成された。例話の主人公 の名は, 被験児が男子の場合太郎と次郎にし，被験児 が女子の場合花子と真知子にした。この例話の完全な 原版は以下のとおりである(なお，下線部は意図情報、波下 線部は結果情報を示す)。

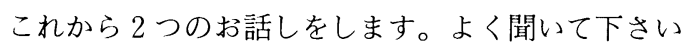
ね。太郎 (花子) ちゃんは, お母さんが留守の間, マン ガのテレビを見ています。おなかがすいていたので, おやつがほしくなりました。それで，お客さん用にお 母さんが戸棚に隠してあるお菓子をとろうとしました。 お菓子のそばには，コップが何個か置いてありました。 お菓子は高い所にあったので，手をのばしてとろうと したら，热菓子のそばにあったコップが1個床に落ち て割热てしまいました。

では, 次に次郎 (真知子) ちゃんのお話しね。次郎 (真 知子)ちゃんは, お母さんが夕飯を作っている間, マン ガの本を読んでいました。お母さんに御飯に呼ばれた ので，台所の方に行こうとしました。ところが，ドア のうしろにイスがあって，イスの上に何個かのコップ がのっているお盆がありました。次郎 (真知子) ちゃん はドアのうしろにそんなものがあるとは知らないで ドアを開けたので，10個のコップが床に落ちて割れて しまいました。

以上の例話のひとりの主人公の意図あるいは結果の 情報を与えないことによって, 実験条件を操作した。 すなわち, 各例話を 3 つのシーンに分け(物語の序の部分, 意図の情報が与えられる部分, 結果の情報が与えられる部分), 各 主人公の意図あるいは結果の情報を, 与えないことに より，傊情報の条件を操作した。例えば，意図の悪 い例話中の結果の情報のみが除かれる条件( $\mathrm{BC}$ 群)の条 件では, 以下のように, 物語が与えられた。なお, 各 主人公の例話について言及する順序は, 久損情報のあ る例話が後になるようにされた。

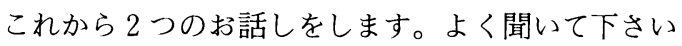

ね。次郎（真知子）ちゃんは，お母さんが夕飯を作って いる間, マンガの本を読んでいました。お亩さんに御 飯に呼ばれたので，台所の方に行こうとしました。と ころが，ドアのうしろにイスがあって，イスの上に何 個かのコップがのっている扔盈がありました。次郎(真 知子)ちゃんは，ドアのうしろにそんなものがあるとは 知らないでドアを開けたので，10個のコップが床に落 ちて割れてしまいました。

では，次に太郎（花子）ちゃんの打話し权。太郎（花 子)ちゃんは, お母さんが留守の間, マンガのテレビを 見ています。おなかがすいていたので，おやつがほし くなりました。それで，お客さん用にお母さんが户棚 に隠してあるお菓子をとろうとしました。お菓子のそ ばには,コップが何個か置いてありました。

手続 幼稚園の 1 室において個別に面接がなされた。 面接は，3名の実験者により行われた。各実験者は, 無作為な順序で各実験条件に取組んだ。

これら Piaget (1932) の道徳判断課題の過失の例話 で，主人公の意図が悪いのに損失が小の条件と，意図 が善いのに損失が大の条件の 2 種類の例話が同一の被 験者に読み聞かされた。ただし，例話が実験者により， 読まれる際，描画が提示された(FIG.1参照)。例話を読 み聞かせる順序は, 無作為に変えられた。なお, 男子 に対しては，例話の主人公を男子 (太郎, 次郎) とし，女 子に対しては, 主人公を女子 (花子, 真知子) とした。意 図が悪いのに損失が小の例話の主人公を太郎または花 子とし, 意図が善いのに損失が大の条件の主人公を次 郎または真知子とした。各例話を 3 つのシーンに分け, 意図あるいは結果に関する情報を, 白紙により隠し, その部分の情報を口頭でも与えないことにより，欠損 情報の条件を操作した。

例話の提示後, 以下の質問がなされた。(1)太郎(花子) ちゃんと次郎(真知子)ちゃんは, どちらが悪いと思う？ (2)それは，どうして？(3)このお話についてもっと聞 きたいことがある？(もし, 欠損情報について, 被験児が斦問 したとしたら，正しい情報を後で教えてあげると言う)(4)ここの ○○ゃんの抢話 (描画の欠損部分を指して言う) は，言わ なかったけど，どんなことがあったと思う？(5)本当 は, ○○ちゃんのお話では, ○○だったんだけど(と言っ て欠賣情報を教える), 太郎 (花子) ちゃんと次郎 (真知子) ちゃんは，どちらが悪いと思う？，の 5 つであった。 ここで(1)の質問は欠損情報のある状態での道徳判断, (2)の質問は欠損情報のある状態での道徳判断の理由, (3)の質問は欠損情報のある状態での道徳判断における 被験児の因果情報についての自発的な情報探索，(4)の 


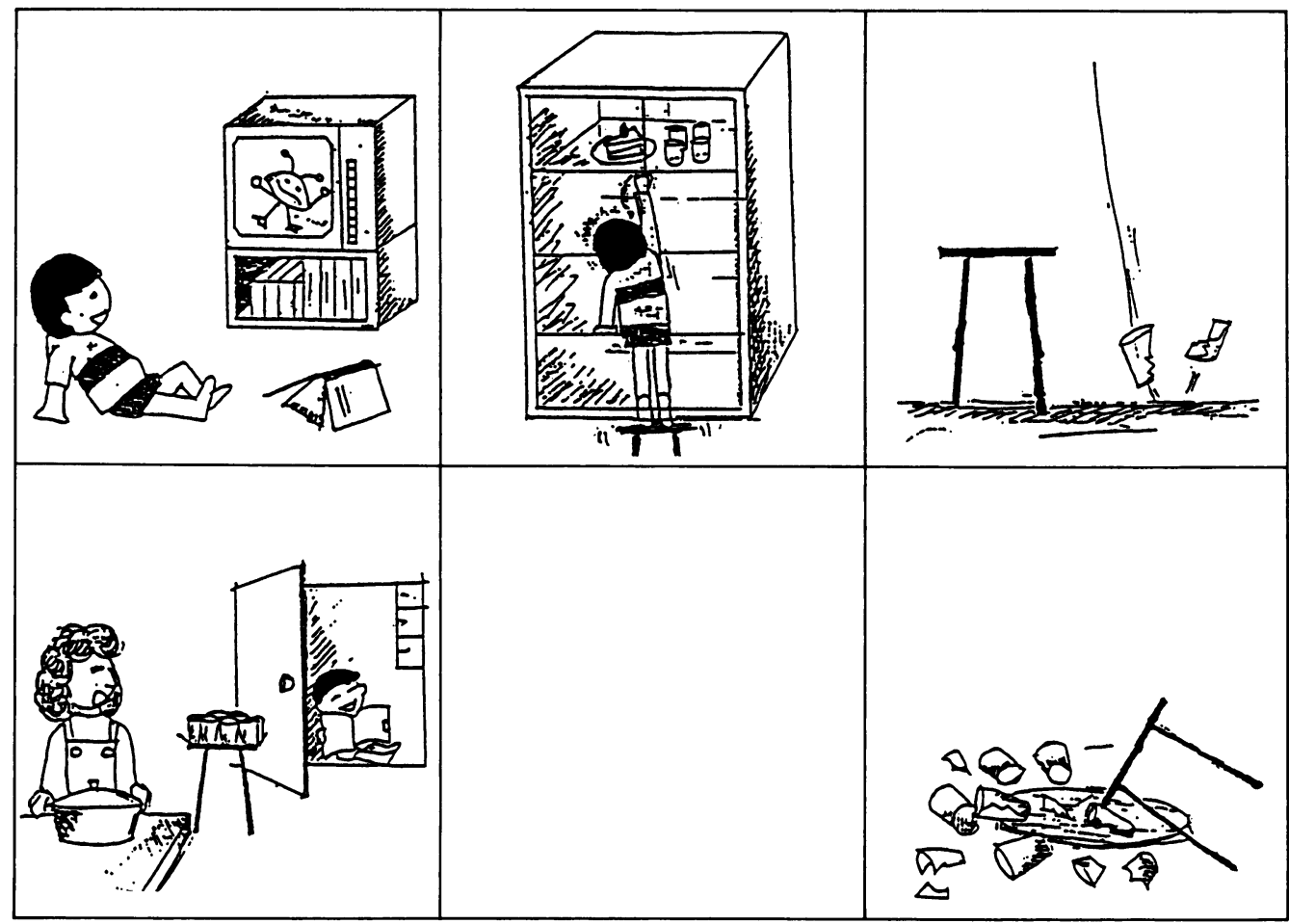

FIG. 1 A condition for an absence of intent information about the good motive person (GI condition)

質問は欠損情報のある状態での因果推論を，(5)の質問 は欠損情報を教えた後の道徳判断に関するものである。

\section{結果}

欠損情報のある状態での道徳判断 “太郎(花子)ちゃ んと次郎（真知子）ちゃんは，どちらが悪いと思う？” という質問に対しての各条件での被験児の回答結果を TABLE 1 に示す。全条件をとおしてみると, “太郎(花 子）ちゃんが悪い”と回答した者（主観的判断者）が $42.4 \%$, “次郎 (真知子) ちゃんが悪い”と回答した者(客 観的判断者) が47.5\%, “わからない”などの 2 者のうち どちらが悪いかについて回答しなかった者（無回答者) が10.2\%であった。

道徳判断と実験条件を要因とする階層的対数線形分 析 (Everitt, 1977 ; Haberman, 1978) を行った。まず，道 徳判断と実験条件との交互作用が有意であり $\left(x^{2}=\right.$ $13.99, \mathrm{df}=6, \mathrm{p}<.05)$, 道徳判断のパターンに条件差がある ことが示された。なお，この交互作用効果の検定は， 通常の独立性の $\chi^{2}$ 検定と同じことになる (Everitt, 1977)。また, 主効果は, 道徳判断の効果が有意であり $\left(\chi^{2}=17.54, \mathrm{df}=2, \mathrm{p}<.001\right)$, 下位検定の結果, 客観的判断
TABLE 1 Moral judgement under the missing information for each condition

\begin{tabular}{lcrrcc}
\hline \multirow{2}{*}{$\begin{array}{l}\text { Type of moral } \\
\text { judgement }\end{array}$} & \multicolumn{4}{c}{ Condition } \\
\cline { 2 - 5 } & GI & BI & GC & BC \\
\hline Subjective judgement & $4(25.0 \%)$ & $2(15.4 \%)$ & $11(73.3 \%)$ & $8(53.3 \%)$ \\
Objective judgement & $9(56.3 \%)$ & $10(76.9 \%)$ & $3(20.0 \%)$ & $6(40.0 \%)$ \\
No Judgement & $3(18.8 \%)$ & $1(7.7 \%)$ & $1(6.7 \%)$ & $1(6.7 \%)$ \\
\hline
\end{tabular}

Notes. The first entry in the table is the number of subjects in that cell. The second entry in the table in the percentage of subjects in each condition.

と主観的判断の間には有意差はなく共に無回答より有 意に多いということが明らかになった。

次に, 観察度数と期待度数との差を標準正規分布に 従うように調整した残差分析 (Haberman, 1978) を行い, その結果を TABLE 2 に示した。TABLE 2 に示されてい るように, BI 群では客観的判断が有意に多く, GC 群 では主観的判断が有意に多い。また，この残差の符号 をみるとわかるように, 意図情報を欠損させた条件で は客観的判断が比較的多く出現し, 結果情報を欠損さ せた条件では主観的判断が比較的多く出現している。 
TABLE 2 Adjusted standardized chi-square residuals in the moral judgement under the missing information

\begin{tabular}{lcccc}
\hline Type of moral & \multicolumn{4}{c}{ Condition } \\
\cline { 2 - 5 } judgement & GI & BI & GC & BC \\
\hline Subjective judgement & $2.3^{*}$ & $-2.2^{*}$ & $2.8^{* *}$ & 1.0 \\
Objective judgement & $-1.8^{(*)}$ & $2.4^{*}$ & $-2.5^{*}$ & -.7 \\
No Judgement & -1.4 & -.3 & 1.3 & -.5 \\
\hline
\end{tabular}

Note. The entry in the table in the abjusted standard ized chi-square residuals. If the moral judgement and the condition are statistically independent, the residuals are approximately normally distributed with a mean of zero and standard deviation of one.

$$
\text { ** } \mathrm{p}<.01 \quad * \mathrm{p}<.05 \quad(*) 0.5<\mathrm{p}<.10 .
$$

道徳判断の理由 “それは，どうして?”という欠 損情報のある状態での道徳判断の理由に関する質問に 対しての被験児の回答を，(1) “ケーキをとろうとした から”などのように意図に言及した理由，(2) “コップ をわったから”などのように結果に言及した理由，(3) “わからない”や無回答などの理由なし反応の 3 種類 に分類した。各条件での被験児の回答結果を TABLE 3 に示した。全条件をとおしてみると，意図に言及した 理由は $37.3 \%$ ，結果に言及した理由は $44.1 \%$ であり， 理由無しの反応は18.6\%であった。

TABLE 3 Reason for the moral judgement in each condition

\begin{tabular}{lcccc}
\hline \multirow{2}{*}{$\begin{array}{l}\text { Type of reason for } \\
\text { judgement }\end{array}$} & \multicolumn{4}{c}{ Condition } \\
\cline { 2 - 5 } & GI & BI & GC & BC \\
\hline $\begin{array}{l}\text { Reason related to intent } \\
\text { Reason related to }\end{array}$ & $3(18.8 \%)$ & $1(7.7 \%)$ & $10(66.7 \%)$ & $8(53.3 \%)$ \\
$\begin{array}{l}\text { consequence } \\
\text { The others }\end{array}$ & $11(68.8 \%)$ & $6(46.2 \%)$ & $4(26.7 \%)$ & $5(33.3 \%)$ \\
\hline
\end{tabular}

Note. The first entry in the table is the number of subjects in that cell. The second entry in the table is the percentage of subjects in each condition.

道徳判断理由と実験条件を要因とする階層的対数線 形分析を行った。まず，道徳判断理由と実験条件との 交互作用が有意であり $\left(\chi^{2}=19.67, \mathrm{df}=6, \mathrm{p}<.01\right)$, 道徳判 断理由のパターンに条件差があることが示された。ま た，道徳判断理由の主効果が認められ $\left(\chi^{2}=6.67, \mathrm{df}=2, \mathrm{p}\right.$ く.05), 下位検定の結果, 結果に言及した理由と意図に言 及した理由との間には有意差がなく共に理由なしょり も有意に多いということが明らかになった。
次に，観察度数と期待度数との差を標準正規分布に 従うように調整した残差分析を行い，その結果を TABLE 4 に示した。TABLE 4 に示されているように, GI 群では結果に言及した理由が有意に多くなり，GC 群では意図に言及した理由が有意に多くなっている。 また，この残差の符号をみるとわかるように，意罒情 報を欠損させた条件では道徳判断が結果に関する理由 によりなされ，結果情報を欠損させた条件では道徳判 断が意図に関する理由によりなされる傾向がある。

TABle 4 Adjusted standardized chi-square residuals in the reason for the moral judgement in each condition

\begin{tabular}{lcccc}
\hline $\begin{array}{l}\text { Type of reason for } \\
\text { judgement }\end{array}$ & \multicolumn{4}{c}{ Condition } \\
\cline { 2 - 5 } & GI & BI & GC & BC \\
\hline Reason related to intent & $-1.8^{(*)}$ & $-2.5^{*}$ & $2.7^{* *}$ & 1.5 \\
Reason related to conse- & $2.3^{*}$ & .2 & -1.6 & -1.0 \\
quence & -.7 & $2.9^{* *}$ & -1.4 & -.6 \\
The others & $* \mathrm{p}<.05$. & $(*)$ & $0.5<\mathrm{p}<.10$.
\end{tabular}

因果情報探索 “このお話についてもつと聞きたい ことがある？”という質問に対して，因果関係を示す 欠損情報について実験者に質問した被験児の各条件に おける度数をTABLE 5 に示した。全条件をとおしてみ ると，因果関係を示す欠損情報について実験者に質問 した被験児は $8.5 \%$ と極めて少なく,例話の因果関係に 関心を示す被験児が少ないことを示している。

因果情報探索と実験条件を要因とする階層的対数線 形分析を行った。まず，因果情報探索と実験条件との 交互作用の有意傾向が認められた $\left(\chi^{2}=6.25, \mathrm{df}=3, \mathrm{p}<\right.$. 10)。また, 因果情報探索の主効果が認められ $\left(\chi^{2}=47.55\right.$.

TABLE 5 Information seeking related to causal relationship for each condition

\begin{tabular}{|c|c|c|c|c|}
\hline \multirow{2}{*}{ Information seeking } & \multicolumn{4}{|c|}{ Condition } \\
\hline & GI & BI & $\mathrm{GC}$ & $\mathrm{BC}$ \\
\hline $\begin{array}{l}\text { Causal information } \\
\text { seeking }\end{array}$ & $0(0.0 \%)$ & $2(15.4 \%)$ & $0(0.0 \%)$ & $3(20.0 \%)$ \\
\hline $\begin{array}{l}\text { No causal information } \\
\text { seeking }\end{array}$ & $16(100.0 \%)$ & $11(84.6 \%)$ & $15(100.0 \%)$ & $12(80.0 \%)$ \\
\hline
\end{tabular}

Note. The first entry in the table is the number of subjects in that cell. The second entry in the table in the percentage of subjects in each condition. 
$\mathrm{df}=2, \mathrm{p}<.001)$ 。下位検定の結果，因果情報探索がない場 合の方が因果情報探索がある場合より有意に多いとい うことが明らかになった。

次に, 残差分析を行い, その結果を TABLE 6 に示し た。TABLE 6 に示されているように, BC 群が最も因果 情報探索が多いことがわかる。この結果は，意図が社 会的に望ましくない場合の結果の予測において，被験 児が最も興味を持ちやすいことを示唆している。

TABLE 6 Adjusted standardized chi-square residuals in the information seeking related to causal relationship

\begin{tabular}{|c|c|c|c|c|}
\hline \multirow{2}{*}{ Information seeking } & \multicolumn{4}{|c|}{ Condition } \\
\hline & GI & BI & $\mathrm{GC}$ & $\mathrm{BC}$ \\
\hline $\begin{array}{l}\text { Causal information } \\
\text { seeking }\end{array}$ & -1.4 & 1.0 & -1.4 & $1.9^{(*)}$ \\
\hline $\begin{array}{l}\text { No causal information } \\
\text { seeking }\end{array}$ & 1.4 & -1.0 & 1.4 & $-1.9^{(*)}$ \\
\hline
\end{tabular}

因果推論 “ここの○○ちゃんのお話は, 言わなかつ たけど，どんなことがあったと思う？”という因果推 論についての質問に，何等かの推測を行って回答した 被験児の各条件における度数を TABLE 7 に示した。全 条件をとおしてみると，32.2\%の被験児が何等かの推 論を行っているが, 残りの $67.8 \%$ の被験児は, “わから ない”と答えている。このことは，大半の被験児が因 果推論を行っていなかったことを示している。条件別 に，複数名の被験児によって報告された因果推論の内 容を述べると，まず，GI 群では“コップをわった”が 2 名 (12.5\%), BI 群でも“コップをわった”が 2 名 (15. $4 \%) ， G C$ 群では“拇さんに抗こられた”が 2 名 (13.3\%)，BC群では“コップをわった”が5 名 (33.3\%)，“ケーキを食べているところ”が 3 名 $(20.0 \%)$ であった。

因果推論の有無と実験条件を要因とする階層的対数 線形分析を行ったところ, まず，因果推論と実験条件 との交互作用が有意であった $\left(\chi^{2}=8.02, \mathrm{df}=3, \mathrm{p}<.05\right)$ 。ま た, 因果推論の主効果が認められ $\left(\chi^{2}=7.64, \mathrm{df}=2, \mathrm{p}\right.$ 〈.01), 下位検定の結果, 因果推論がない被験者の方が何 等かの因果推論をした被験児よりも有意に多いという ことが明らかになった。

次に, 残差分析を行い, その結果を TABLE 8 に示し た。TABLE 8 に示されているように, BC 群に因果推論
TABle 7 Causal inference about the missing information for each condition

\begin{tabular}{lcccc}
\hline \multirow{2}{*}{ Causal inference } & \multicolumn{4}{c}{ Condition } \\
\cline { 2 - 5 } & \multicolumn{1}{c}{ GI } & BI & GC & BC \\
\hline Causal inferaence & $5(31.3 \%)$ & $2(15.4 \%)$ & $3(20.0 \%)$ & $9(60.0 \%)$ \\
No causal inference & $11(68.8 \%)$ & $11(84.6 \%)$ & $12(80.0 \%)$ & $6(40.0 \%)$ \\
\hline
\end{tabular}

Note. The first entry in the table is the number of subjects in that cell. The second entry in the table is the percentage of subjects in each condition.

Table 8 Adjusted standardized chi-square residuals in causal inference about the missing information

\begin{tabular}{lcccc}
\hline & \multicolumn{5}{c}{ Condition } \\
\cline { 2 - 5 } Information seeking & GI & BI & GC & BC \\
\hline $\begin{array}{l}\text { Causal information } \\
\text { seeking }\end{array}$ & -.1 & -1.5 & -1.2 & $2.7^{* *}$ \\
$\begin{array}{l}\text { No causal information } \\
\text { seeking }\end{array}$ & .1 & 1.5 & 1.2 & $-2.7^{* *}$ \\
\hline Note. $\quad * * \mathrm{p}<.01$ & $* \mathrm{p}<.05$ & $(*) 0.5<\mathrm{p}<.10$.
\end{tabular}

をした被験児が最も多いことがわかる。この結果は， 意図が社会的に望ましくない場合の結果の予測的推論 が被験児にとって, 最も容易であったことを示唆して いる。

\section{欠損情報のない状態での道徳判断 “本当は,} ○ちゃんのお話では，○○だったんだけど，太郎(花子) ちゃんと次郎（真知子）ちゃんは，どちらが悪いと思 う?”という質問に対しての各条件での被験児の回答 結果を TABLE 9 に示す。全条件をとおしてみると,“太 郎（花子）ちゃんが悪い”と回答した者（主観的判断者） が50.8\%，“次郎 (真知子) ちゃんが悪い”と回答した者 (客観的判断者）が $40.7 \%$ ，“わからない”などの 2 者の うちどちらが悪いかについて回答しなかった者(無回答 者）が $8.5 \%$ であった。

道徳判断と実験条件を要因とする階層的対数線形分 析を行った。まず，因果推論と実験条件との交互作用 は，欠損情報がある場合での道徳判断の結果と異なり 有意でなかった。一方, 道徳判断の主効果は認められ $\left(\chi^{2}=21.2, \mathrm{df}=2, \mathrm{p}<.001\right)$, 下位検定の結果, 客観的判断 と主観的判断との間には有意差はなく共に無回答より も有意に多いということが明らかになった。 
TABLE 9 Moral judgement under no missing information for each condition

\begin{tabular}{lcccc}
\hline \multirow{2}{*}{$\begin{array}{l}\text { Type of moral } \\
\text { judgement }\end{array}$} & GI & BI & GC & BC \\
\cline { 2 - 5 } & $9(56.3 \%)$ & $8(61.5 \%)$ & $7(46.7 \%)$ & $6(40.0 \%)$ \\
Subjective judgement & $9(37.5 \%)$ & $4(30.8 \%)$ & $6(40.0 \%)$ & $8(53.3 \%)$ \\
Objective judgement & $6(6.3 \%)$ & $1(7.7 \%)$ & $2(13.3 \%)$ & $1(6.7 \%)$ \\
No Judgement & $1(6)$ \\
\hline
\end{tabular}

Notes. The first entry in the table is the number of subjects in that cell. The second entry in the table is the percentage of subjects in each condition.

\section{考察}

欠損情報のある状態での道徳判断を検討したところ, 判断のパターンに条件差があることが認められた。ま た，残差分析 (Haberman, 1978) の結果は，意図の悪い 例話中の意図の情報のみが除かれる条件 (BI 群)では客 観的判断が有意に多く, 意図の善い例話中の結果の情 報のみが除かれる条件(GC 群)では主観的判断が有意に 多いことを示した。さらに，残差の符号から，意図情 報を欠損させた条件では客観的判断が比較的多く出現 し，結果情報を欠損させた条件では主観的判断が比較 的多く出現していることが示された。この結果の原因 に関して，2つの可能性が考えられる。ひとつは, 被 験児が欠損情報について何等かの推測を行って判断し たという可能性であり, 結果が悪いと意図も悪い(BI 群 の場合), 意図が悪くないと結果も悪くない( $\mathrm{GC}$ 群の場合) といった欠損情報に対する推論が働いていたことが示 唆される。他のひとつの可能性は, 被験児が欠損情報 のない比較できる次元のみを考慮して, 欠損情報のあ る次元に関してはほとんど考慮を行わなかったという ものである。

この 2 つの可能性は, 欠損情報のある状態での道徳 判断の理由の分析結果からも推察される。すなわち, 本研究では, 欠損情報のある状態での道徳判断の理由 に関する質問に対しての被験児の回答を，(1)意図に言 及した理由，(2)結果に言及した理由，(3)理由なし反応 の 3 種類に分類し, これらの回答パターンに条件差が あるかを検討したところ，有意差が認められた。 TABLE 4 に示されているように，BI 群と GI 群では結 果に言及した理由が有意に多くなり，GC群では意図 に言及した理由が有意に多くなっている。この残差の 符号をみるとわかるように，意図情報を欠損させた条 件では道徳判断が結果に関する理由によりなされ, 結
果情報を欠損させた条件では道徳判断が意図に関する 理由によりなされる傾向がある。この結果は, 久損情 報のある状態での道徳判断と対応している。つまり， この結果の原因に関して, 前述の 2 つの可能性が考え られるのである。

Leon (1980)は，結果情報または意戝情報のみを小学 生と大学生に与えて道徳判断を評定法で行わせ, 意図 と結果の両情報を提示した場合との比較を行った。そ の結果, 小学生では, 両方の情報を与えられた場合は Anderson (1974) の平均モデルでの当てはまりがよく なったが，一方のみの情報を与えられた場合には，大 学生のように，両方の情報を与えた場合の結果との間 に平行な関係はみられなかった。このことは，小学生 では，意図あるいは結果だけの情報を与えられても他 方の欠損情報を大学生のように推論することがないこ とを示唆している。Leon (1980) の研究結果は, 小学生 が意図あるいは結果だけの情報を与えられた場合，欠 損情報を推測してその推測値をもとに情報統合を行う ことがほとんどないことを示唆している。

本研究に扔いても, 因果情報探索や因果推論の分析 結果からみて, Leon (1980) の研究結果と同様, 被験児 が意図あるいは結果だけの情報を与えられた場合，欠 損情報を推測してその推測値をもとに情報統合を行う ことはあまり多くないと結論できそうである。すなわ ち, まず, 本研究の因果情報探索の分析結果から, 因 果関係を示す欠損情報について実験者に質問した被験 児は $8.5 \%$ と極めて少なく,例話の因果関係に関心を示 す被験児が少ないことが明らかにされている。また， 因果推論の分析結果から，32.2\%の被験児が何等かの 推論を行っているが, 残りの $67.8 \%$ の被験児は, “わか らない”と答えており,多くの被験児が因果推論を行っ ていなかったことが明らかにされた。

このことから，前述した $2 つ の$ 可能性については, 被験児が欠損情報について何等かの推測を行って判断 したという可能性よりも，被験児が欠損情報のない比 較できる次元のみを考慮して欠損情報のある次元に関 してはあまり考慮を行わなかったという可能性の方が より妥当であることが示唆される。

このことに関連して, 柴田 (1981) は, 次の 5 つのレ ベルが発達過程にみられるのではないかと述べている。 まず，レベル 0 の子供は, 道徳的判断に必要な因果推 論をする論理的思考能力を持っていない。次に, レ心゙ ル1の子供は, 論理的思考能力を持っているが, 人間 の行動についての因果推論をする際には，その能力を 用いることができない。レベル 20 子供は, 行為の結 
果としての損失にのみ注意を払って抢り，意図や動機 は結果がポジティブな場合にだけ考慮され，結果がネ ガティブな場合は考慮されない。レベル 3 では, 意図 がポジティブでもネガティブでも考虑される。最後に レベル 4 では, 複雑な状況に含まれるさまざまな要因 を考慮することができる。

本研究の結果から, 多くの被験児は柴田 (1981) の指 摘するレベル 1 にいることが示唆される。しかし，本 研究の被験児がすべて人間行動について適切な因果推 論を行えないレベル 1 の段階にいるわけではない。す なわち，少人数ながら因果情報探索や因果推論を行っ た被験児がいたからである。また，本研究の被験児は， 欠損情報についての因果推論をほとんど行わなかった が，与えられた情報に関しては因果情報を統合して判 断していると考えられる。このことは，欠損情報を教 えられた後も一貫して以前と同じ判断をしていた被験 児は26名(44.1\%)しかおらず，大半の被験児が欠損情報 を教えられた後に道徳判断を変えていることからも推 察できる。

それでは, 次に, 道徳判断における因果情報探索や 因果推論の条件差に焦点を絞って，因果推論における 非対称性の問題について考察を行う。因果情報探索に ついては，条件間に統計的有意差の傾向が認められ， TABLE 6 に示されているように，残差分析から BC 群 が最も因果情報探索が多いことがわかった。この結果 は，意図が社会的に望ましくない場合の結果の予測に おいて, 被験児が最も興味を持ちやすいことを示唆し ている。また，因果推論に関しては，何等かの因果推 論を行った被験児と行わなかった被験児との条件差を 検定した結果，条件間に統計的有意差が認められた。 残差分析から, TABLE 8 に示されているように, BC 群 に因果推論をした被験児が最も多いことがわかる。こ の結果は, 意図が社会的に望ましくない場合の結果の 予測的推論が被験児にとって最も容易であったことを 示唆している。

本研究の結果は, 因果情報探索においても因果推論 においても，原因 (意図) が社会的に望ましくない場合 の結果の予測的推論が被験児にとって最も容易であっ たことを示唆しており，幼児においても，予測過程と 帰属過程の非対称性, 社会的望ましさに関する因果推 論の非対称性がみられることを示している。幼児にお いてこのような因果推論の非対称性が見られることは, このような非刘称性を示す心的機制が発達の初期段階 で形成されていることを示唆するものである。

予測過程と帰属過程の非対称性は，ヒューリスティ
クスやスキーマのような人間の認知過程によって説明 され得る。Tversky \& Kahneman（1982）によると， 人間は, スキーマなどの心的モデルを因果推論に際し て使用する。彼らは, 予測過程では, 意図, 動機, 人 格などの既成の心的モデルを容易に適用できるが，帰 属過程では，心的モデルを再構成しなければならない ことがあり推論の困難性が増すと指摘している。おそ らく，幼児においても，このような心的モデルの機制 が働いているのであろう。本研究の結果は, 幼児と成 人の因果推論におけるこのような心的モデル操作の機 能が基本的には同じであることを示唆している。

つぎに，社会的望ましさに関する非対称性について 考察する。Jones \& Davis（1965）の示唆によると，社 会的に望ましくない行為は，社会的規範を逸脱してお り，特異であるので，原因を特定しやすい。同様な理 由で, 社会的に望ましくない原因は, 結果を推論しや すいのかもしれない。しかし，この説明は，幼児には， 当てはまらないように思われる。というのは，幼児は， 社会的に望ましくない行為を数多くする中で母親ある いは父親の教育によってそれらの行為を修正していく と考えられるので，社会的に望ましくない原因や結果 は Jones \& Davis（1965）の指摘するような情報価をも たないと考えられるからである。むしろ，社会的に望 ましくない行為に対する罰の学習結果が因果推論過程 に非対称性を生じさせたと考える。

最後に, 本研究における方法論的問題点の考察を行 う。まず，第 1 の問題は，課題の人工性の問題である。 本研究で用いた道徳判断課題は, Piaget (1932) の課題 と基本的に同じものであるが，このような課題は，そ の子供にとってどの程度具体性をもっているのかが明 らかでない。例えば, 本研究の課題では, 被験児のほ とんどが因果情報探索や因果推論ができていなかった が, 日常の道徳判断状況では因果情報探索や因果推論 を自発的にしている可能性が残る。このような問題点 を克服するには，今後の実験ではより現実に近い場面 で検討することが必要になってくるだろう。また，次 に第 2 の問題点であるが，これは，対象とした被験児 の年齢に関するものである。本研究では，6才児を対 象にした実験しか行わなかったが, 道徳判断状況にお ける因果情報探索や因果推論の発達を今後検討するた めには，種々の年齢集団を検討していく必要があるだ ろう。

\section{引用文献}

Anderson, N.H. 1974 Cognitive algebra : Integra- 
tion theory applied to social attribution. In L. Berkowitz (Ed.). Advances in experimental social psychology. Vol. 7. New York : Academic Press. 1-101.

Buchanan, J.P., \& Tompson, S.K. 1973 A quantitative methodology to examine the development of moral judgement. Child Development, 44, 186-189.

Costanzo, P.R., Coie, J.D., Grumet. J.F., Farnill, D. 1973 A reexamination of the effects of intent and consequences on children's moral judgements. Child Development, 44, 154-161.

Everitt, B.S. 1977 The analysis of contingency tables. London: Chapman and Hall. (B.S. I ヴェリット著 山内光哉(監訳) 1980 質的デー 夕の解析 新曜社)

Farnill, D. 1974 The effects of social-judgement set on children's use of intent information. Journal of Personality, 42, 276-289.

Grueneich, R. 1982 The development of children's integration rules for making moral judgement. Child Development, 53, 887-894.

Gutkin, D.C. 1972 The effect of systematic story changes on intentionality in children's moral judgement. Child Development, 43, 187-195.

Haberman, S.J. 1978 Analysis of qualitative data. Vol. 1 New York : Academic Press.

Hebble, P.W. 1971 The development of elementary school children's judgement of intent. Child Development, 42, 1203-1215.

Jones, E.E., \& Davis, K.E. 1965 From acts to dispositions : The attribution process in person perception. In L. Berkowitz (Ed.), Advances in experimental social psychology. Vol. 2 New York : Academic Press. 219-266.

Kahneman, D., Slovic, P., \& Tversky, A. (Eds.) 1982 Judgement under uncertainty: Heuristics and biases. Cambridge : Cambridge University Press.

Leon, M. 1980 Integration of intent and consequence information in children's moral judgement. In F. Wilkening, J. Becker, \& $\mathrm{T}$.
Trabasso (Eds.), The integration of information by children. Hillsdale, N.J. : Erlbaum. 71 $-97$.

二宮克美 1980 児童の道徳判断に関する一研究 - Gutkin の 4 段階説の実験的検討—— 教育 心理学研究, 28, 18-27.

二宮克美 1982 児童の道徳判断に関する一研究 -Gutkinの 4 段階説の発達同時性の検討一 教 育心理学研究, 30, 282-286.

Piaget, J. 1923 Le langage et la pens chez l'enfant. Delachaux et Niestle（J. ピアジェ著 大 伴茂訳 1954 児童の自己中心性 同文書院)

Piaget, J. 1932 Le jugement morale chez l'enfant. Alcan. (J. ピアジェ著 大伴茂訳 1956 児童 道徳判断の発達 同文書院)

坂上道子・難波和明・小倉康仁 1982 子どもの道徳 的判断に関する研究 (動機と結果の重みづけの 発達 一加法的順序構造に注目して一）教育心 理学会第24回総会, 228-229.

柴田幸一 1981 子どもたちは道徳判断において, な ぜ動機に基づいた適切な反応をすることができな いのか 一道徳判断に扔いて子どもの発達水準を 設定する一つの試み一静岡大学教育学部研究報 告 (人文・社会科学編) , 32, 163-171.

Surber, C.F. 1977 Developmental processes in social inference : Averaging of intentions and consequences in moral judgement. Developmental Psychology, 13, 654-665.

Tversky, A., \& Kahneman, D. 1982 Causal schemas in judgements under uncertainty. In D. Kahneman, P. Slovic, \& A. Tversky (Eds.), Judgement under uncertainty : Heuristics and biases. Cambridge : Cambridge University Press. 117-128.

\section{付 記}

本研究の実施にあたり, 調査時点で筑波大学生で あった小平真季さんに大きな協力を得ましたことを深 く感謝します。また, 私立ひたち学院の先生方, なら びに園児の皆様のご協力をいただきましたことに厚く お礼を申しあげます。

（1990年 6 月22日受稿） 